\title{
Metal-ligand multiple bonds. Oxo, imido and nitrido complexes of ruthenium and osmium
}

\author{
Chi-Ming Che \\ Department of Chemistry, The University of Hong Kong, \\ Pokfulam Road, Hong Kong.
}

\begin{abstract}
Ru}=\mathrm{O}$ complexes have been demonstrated to be competent oxidants for oxidation of saturated hydrocarbons and epoxidation of alkenes. Photoexcitation of transdioxoosmium(VI) gives rise to super-oxidizing complexes having $E^{0}>2.2 \mathrm{~V}$ vs. n.h.e. Some cationic $\mathrm{Ru} \equiv \mathrm{N}$ and $\mathrm{Os} \equiv \mathrm{N}$ complexes are good model system for study of the mechanism of metalcatalysed oxidation of ammonia to nitrite and activation of dinitrogen molecule. With 2,3-diamino-2,3-dimethylbutane as ligand, reversible Os(IV)-amide/Os(III)-amine and $\mathrm{Ru}(\mathrm{V})$ imido/Ru(II)-amine redox couplexes are observed.
\end{abstract}

\section{INTRODUCTION}

The study of high-valent metal complexes with the metal ion multiply bonded to a heteroatom continues to be an active area of research (1). Of particular interest to us is oxo, nitrido and imido- ruthenium and -osmium complexes in high oxidation states (2). These complexes have strong $\mathrm{d} \pi-\mathrm{p} \pi$ interactions. Because of the high $\mathrm{E}^{0}$ value, the highly oxidizing ruthenium ion would compete with the heteroatom for the bonded electron pair(s). The shift in the electron density would render the heteroatom to be very electrophilic [ Fig.1]. Thus an oxidation state of -II for the oxygen atom in non-oxidizing metal-oxo complexes may be an appropriate description but the situation could be quite different in the cases of ruthenium-oxo and in some high-valent osmium-oxo complexes. To account for the high affinity of $\left[\mathrm{Fe}^{\mathrm{IV}}\left(\mathrm{porp}^{+}\right.\right.$.) $\left.\mathrm{O}\right]$ ( porp $^{+} .=$porphyrinato cation radical $)$in the oxidation of saturated $\mathrm{C}-\mathrm{H}$ bonds, Sawyer and coworkers suggested the term "oxene" to describe the oxygen atom of the $\mathrm{Fe}=\mathrm{O}$ unit (3). In this context, it is likely that $\mathrm{Ru}=\mathrm{O}$ is similar to $\mathrm{Fe}=\mathrm{O}$. We also suggest that a highly oxidizing metal ion would change an organoimido ligand from a 6-electron donor to a 4-electron one. In the extreme case, the metal ion is in a lower oxidation state and the organoimido group behaves like a "nitrene" .

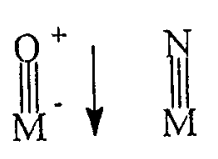<smiles></smiles>

6e-donor

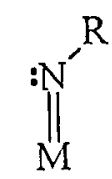

4e-donor

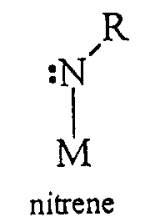

$M$ in lower oxidation state

Fig. $1 \mathrm{~d} \pi-\mathrm{p} \pi$ interactions in $M=O, M \equiv N$, and $M=N R$ complexes

Highly oxidizing cationic ruthenium-nitrido complexes had been suggested to play an important role in oxidation of bound ammonia to nitrite (4) but 
these species have neither been isolated nor characterised. Electrochemical studies by Meyer and coworkers (4) suggested the following reaction scheme.

Scheme 1

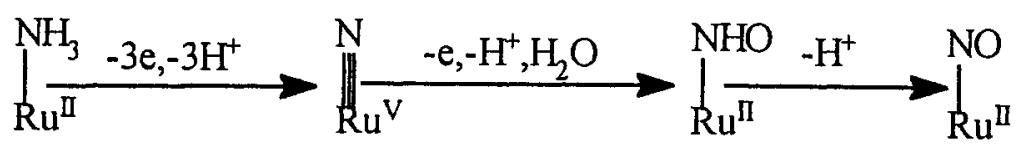

The highly oxidizing $\mathrm{Ru} \equiv \mathrm{N}$ species would undergo intramolecular redox reaction, leading to the oxidation of $\mathrm{N}^{3-}$ to $\mathrm{NO}_{2}^{-}$. Studies of metal-nitrido complexes are also of importance in the context of activation of dinitrogen molecule. Taube and coworkers (5) proposed that disproportionation of a $\mathrm{M}$ $\mathrm{N} \equiv \mathrm{N}-\mathrm{M}$ to two $\mathrm{M} \equiv \mathrm{N}$ units provides an alternative pathway for the activation of dinitrogen molecule.

In general, high-valent osmium complexes are less oxidizing than their ruthenium analogues. However, the oxidizing power of $\mathrm{Os}=\mathrm{O}$ and $\mathrm{Os} \equiv \mathrm{N}$ could be substantially enhanced through excitation with uv-visible light (Scheme 2).

Extensive studies from this laboratory have established the rich redox chemistry of the ${ }^{3}\left[\left(d_{x y}\right)^{1}\left(d_{x z, d y z}\right)^{1}\right]$ excited states of some $\mathrm{Os}(\mathrm{VI})=\mathrm{O}$ $(6,7)$ and $\mathrm{Os}(\mathrm{VI}) \equiv \mathrm{N}$ complexes $(8,9)$.

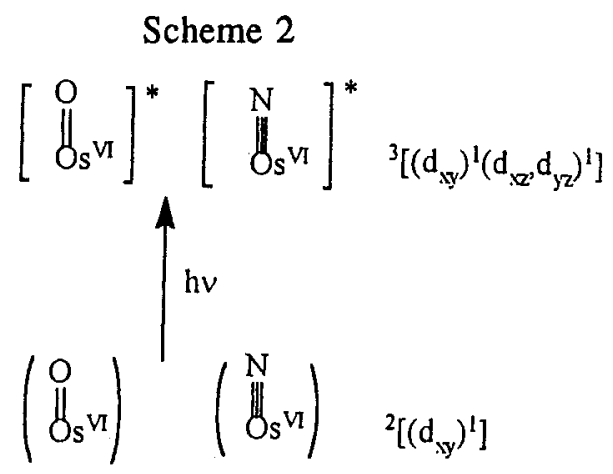

\section{RU'THENIUM-OXO COMPLEXES}

Cationic $\mathrm{Ru}=\mathrm{O}$ complexes can be prepared by oxidation of the corresponding $\mathrm{Ru}-\mathrm{OH}_{2}$ precursor in aqueous solution with $\mathrm{Ce}(\mathrm{IV})$ (2). This method is successful to the preparation of a wide variety of $\mathrm{Ru}=\mathrm{O}$ complexes with different auxiliary ligands and with ruthenium ion in oxidation states IV to VI (2). Even some cis-dioxoruthenium(VI) and monooxoruthenium(V) with $\mathrm{EO}>1.0 \mathrm{~V}$ vs. s.c.e. have been prepared and isolated. Representative examples of the $\mathrm{Ru}=\mathrm{O}$ complexes are shown in Fig. 2 [ $\mathrm{N}_{2} \mathrm{O}_{2}=1,12$-dimethyl-

Ru=O 1.739(2) A

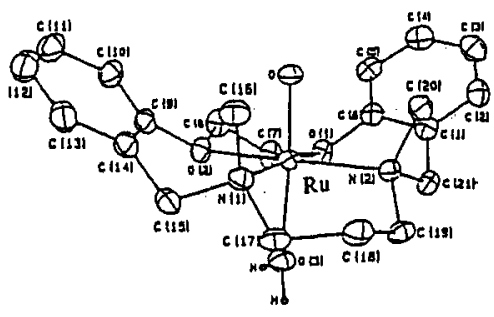

$\left[\mathrm{Ru}^{I V}\left(\mathrm{~N}_{2} \mathrm{O}_{2}\right)\left(\mathrm{H}_{2} \mathrm{O}\right)\right]^{2+}$
$\mathrm{Ru}=\mathrm{O} 1.751(4) \mathrm{A}$

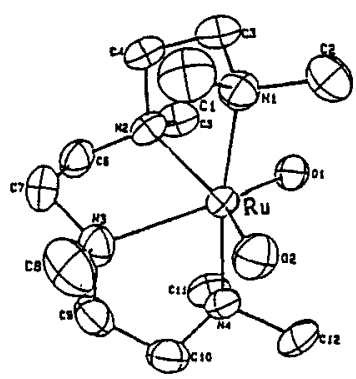

cis- $\left[\mathrm{Ru}^{\mathrm{V}}\left(\mathrm{Tet}-\mathrm{Me}_{6}\right) \mathrm{O}_{2}\right]^{+}$
$\mathrm{Ru}=\mathrm{O}$ 1.717(9), 1.715(9) A

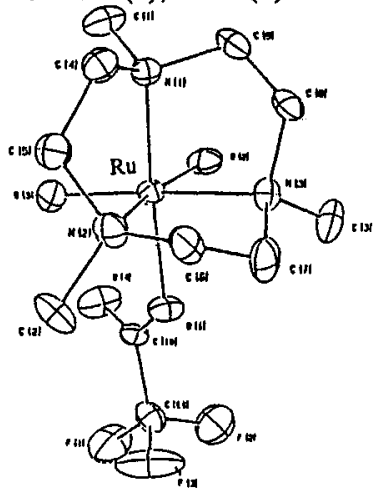

cis-[RuVI $\left(\mathrm{Me}_{3} \operatorname{tacn}\right) \mathrm{O}_{2}\left(\mathrm{CF}_{3} \mathrm{CO}_{2}\right]^{+}$

Fig. 2. X-ray crystal structures of some ruthenium-oxo complexes 
3,4:9,10-dibenzo-1,12-diaza-5,8-dioxacyclopentadecane, Tet-Me $6=\mathrm{N}, \mathrm{N}, \mathrm{N}^{\prime}, \mathrm{N}^{\prime}-$ 3,6-diazaoctane-1,8-diamine, Meztacn = 1,4,7-trimethyl-1,4,7-triazacyclononane ]. These complexes are highly reactive but yet stable enough to allow isolation and even $x$-ray crystal analysis. The success of the syntheses lies on the use of water as solvent for the reaction. Changing the auxiliary ligands could tune the redox properties of both the transdioxoruthenium(VI) and monooxoruthenium(IV) in a systematic manner, as illustrated by the data given in Tables 1 and 2 [ $T M C=1,4,8,11$-tetramethyl1,4,8,11-tetraazacyclotetradecane, $\mathrm{CRMe}_{3}=$ meso-2,3,7,11,12-pentamethyl$3,7,11,17$-tetraazabicyclo-[11.3.1] heptadeca-1(17),13,15-triene, pytn= N, N'dimethyl-bis(2-pyridylmethyl)propylenediamine, bpy=2,2'-bipyridine] .

TABLE 1. EO of some trans-dioxoruthenium(VI)

\begin{tabular}{|c|c|}
\hline Complex & $\begin{array}{l}\mathrm{E}^{\mathrm{o}}(\mathrm{pH} 1.0 \\
\mathrm{V} \text { vs.s.c.e. })\end{array}$ \\
\hline Trans- $\left.\mid \mathrm{Ru}^{\mathrm{V}}(\mathrm{TMC}) \mathrm{O}_{2}\right]^{2+}$ & 0.66 \\
\hline Trans-|Ru1 $\left.\left(\mathrm{CRMc}_{3}\right) \mathrm{O}_{2}\right|^{2+}$ & 0.76 \\
\hline Trans-[Ru ${ }^{\mathrm{VI}}$ (pyln) $\left.\mathrm{O}_{2}\right]^{2+}$ & 0.89 \\
\hline Trans- $\left[\mathrm{Ru}^{\mathrm{Vi}}\left(\mathrm{N}_{2} \mathrm{O}_{2}\right) \mathrm{O}_{2}\right]^{2+}$ & 0.92 \\
\hline Trans-[Ru $\left.{ }^{\mathrm{V}}(\mathrm{bpy}) \mathrm{O}_{2}\right]^{2+}$ & 1.01 \\
\hline
\end{tabular}

TABLE 2. $E^{\mathrm{O}}\left(\mathrm{V}\right.$ vs, s.c.e.) of $\left[\mathrm{Ru}^{\mathrm{IV}}(\text { terpy })(\mathrm{L} \cap \mathrm{L}) \mathrm{O}\right]^{2+}$

\begin{tabular}{|c|c|}
\hline $\mathrm{L} \cap \mathrm{L}$ & $\mathrm{E}^{\circ}$ \\
\hline picolonate anion & $0.45(\mathrm{pH} 7.0)$ \\
\hline 2,2'-bipyridinc & $0.62(\mathrm{pH} 7.0)$ \\
\hline 4,4'-dimethyl-2,2'-bipyridine & $0.55(\mathrm{pH} 7.0)$ \\
\hline $\mathrm{N}, \mathrm{N}^{\prime}, \mathrm{N}^{\prime}, \mathrm{N}^{\prime}$-tetramethyl-1,2-dianimoethane & $0.93(\mathrm{pH} 1.0)$ \\
\hline 6,6'-dichloro-2,2'-bipyridine & $1.13(\mathrm{pH} 1.0)$ \\
\hline
\end{tabular}

The highly oxidizing cis-[RuVI $\left.\left(6,6^{\prime} \text {-dichloro-2,2'-bipyridine }\right)_{2} \mathrm{O}_{2}\right]^{2+}(10)$, trans-[RuVI $\left.\left(5,5^{\prime} \text {-dimethyl-2,2'-bipyridine }\right)_{2} \mathrm{O}_{2}\right]^{2+}(11),\left[\mathrm{RuV}^{2}\left(\mathrm{~N}_{4} \mathrm{O}\right) \mathrm{O}\right]^{2+}\left(\mathrm{N}_{4} \mathrm{OH}\right.$ $=$ bis-[2-(2-pyridyl)ethyl] [2-hydroxy-2-(2-pyridyl)ethyl]amine, 12$)$, $\left[\mathrm{Ru}^{\mathrm{VI}}\left(\mathrm{Me}_{3} \operatorname{tacn}\right) \mathrm{O}_{2}\left(\mathrm{CF}_{3} \mathrm{CO}_{2}\right)\right]^{+}(13)$, and $\left[\mathrm{Ru}^{\mathrm{IV}}\right.$ (terpyridine) $\left(6,6^{\prime}\right.$-dichloro-2,2'bipyridine $) \mathrm{O}^{2+}(14 \mathrm{a})$, all having $\mathrm{E}^{\mathrm{o}}$ greater than $1.0 \mathrm{~V}$ vs. s.c.e at $\mathrm{pH}=1.0$ solution, are capable of oxidizing the $20 \mathrm{C}-\mathrm{H}$ and $30 \mathrm{C}-\mathrm{H}$ bonds of saturated hydrocarbons. In the stoichiometric oxidation of adamantane by these $\mathrm{Ru}=\mathrm{O}$ complexes, the $30^{\circ}(\mathrm{C}-\mathrm{H}) / 2^{\circ}(\mathrm{C}-\mathrm{H})$ bond ratio is usually greater than 20 (2). Large $k_{H} / k_{D}$ ratio of 5 and 12 were found for the oxidation of cyclohexane by $\left[\mathrm{RuV}\left(\mathrm{N}_{4} \mathrm{O}\right) \mathrm{O}\right]^{2+}(14 \mathrm{~b})$ and trans- $\left[\mathrm{RuVI}^{2}\left(5,5^{\prime} \text {-dimethyl-2,2'-bipyridine }\right) \mathrm{O}_{2}\right]^{2+}$ (11), respectively. These findings highlight a $\mathrm{H}$-atom abstraction mechanism for the oxidation of $\mathrm{C}-\mathrm{H}$ bond by the $\mathrm{Ru}=\mathrm{O}$ moiety.

$$
\mathrm{Ru}^{\mathrm{n}}=\mathrm{O}+\mathrm{H}-\stackrel{\mathrm{I}}{\mathrm{C}}-\longrightarrow[\mathrm{Ru}=\mathrm{O}---\mathrm{H}-\stackrel{\mathfrak{C}-}{\mathrm{C}}-] \longrightarrow\left[\mathrm{Ru}^{\mathrm{n}-1}-\mathrm{OH}+\stackrel{\mathfrak{C}}{\mathrm{C}}-\right]
$$

The reaction is facilitated by charge tranfer from the $\mathrm{C}-\mathrm{H}$ bond to the $\mathrm{Ru}=\mathrm{O}$ moiety since other cationic $\mathrm{Ru}=\mathrm{O}$ complexes having lower $\mathrm{E}^{\mathrm{O}}$ are not reactive towards oxidation of saturated $\mathrm{C}-\mathrm{H}$ bonds (15). The importance of charge-

TABLE 3. Rate constants for the oxidation of benzyl alcohol and tetrahydrofuran by trans-dioxoruthenium(VI)

\begin{tabular}{|c|c|c|}
\hline & \multicolumn{2}{|c|}{ Rate constant (mol $\mathrm{dm}^{3} \mathrm{~s}^{-1}$ ) at $298 \mathrm{~K}$ mcasured in aqucous solution } \\
\hline Complex & benzyl alcohol & tetrahydrofuran \\
\hline Trans- $\left[\mathrm{Ru}_{1}{ }^{\mathrm{VI}}(\mathrm{TMC}) \mathrm{O}_{2}\right]^{2+}(0.66 \mathrm{~V})$ & $1.98 \times 10^{-4}$ & \\
\hline Trans- $\left|\mathrm{Ru}^{\mathrm{Vl}}\left(\mathrm{CRMC}_{3}\right) \mathrm{O}_{2}\right|^{2+}(0.76 \mathrm{~V})$ & $3.25 \times 10^{-3}$ & $4.2 \times 10^{-3}$ \\
\hline Trans- $\left|\mathrm{Ru}^{\mathrm{NI}}(\mathrm{pytn}) \mathrm{O}_{2}\right|^{2+}(0.89 \mathrm{~V})$ & $9.31 \times 10^{-1}$ & $1.2 \times 10^{-2}$ \\
\hline Trans- $\left|\mathrm{Ru}^{\mathrm{V}}\left(\mathrm{N}_{2} \mathrm{O}_{2}\right) \mathrm{O}_{2}\right|^{2+}(0.92 \mathrm{~V})$ & $6.85 \times 10^{-1}$ & $1.7 \times 10^{-1}$ \\
\hline Trans- $\left[\mathrm{Ru}^{\mathrm{VI}}(\mathrm{bpy}) \mathrm{O}_{2}\right]^{2+}(1.01 \mathrm{~V})$ & $2.08 \times 10^{1}$ & 3.5 \\
\hline
\end{tabular}


transfer mechanism in $\mathrm{C}-\mathrm{H}$ bond oxidation is also substantiated by the observed linear correlation of $\log$ (rate constants) versus $E^{\circ}(R u=O)$ in the oxidation of benzyl alcohol (16) and tetrahydrofuran (17) by transdioxoruthenium(VI). As shown in Table 3, an increase in the $E^{0}(R u(V I)=O)$ by $340 \mathrm{mV}$ leads to a $10^{5}$ fold increase in rate constants of benzyl alcohol oxidation. Similar effect has also been encountered in the oxidation of tetrahydrofuran (Table 3). Catalytic $\mathrm{C}-\mathrm{H}$ oxidation with $\mathrm{Ru}=\mathrm{O}$ catalysts has also been demonstrated. Both cis-[Rull (6,6'-dichloro-2,2'bipyridine $\left.)_{2}\left(\mathrm{H}_{2} \mathrm{O}\right)_{2}\right]^{2+}(15,18)$ and $\left[\mathrm{RuVI}\left(\mathrm{Me}_{3} \operatorname{tacn}\right) \mathrm{O}_{2}\left(\mathrm{CF}_{3} \mathrm{CO}_{2}\right)\right]^{+}(13)$ are effective catalysts for the oxidation of cyclohexane by $\mathrm{PhIO}$ and/or tBuOOH. The latter Ru-catalyst is of particular interest since the kinetic isotope effect observed in the catalytic cyclohexane oxidation matches those values found in the stoichiometric oxidation by some well-characterised $\mathrm{Ru}=\mathrm{O}$ species. $\mathrm{XO}$ This suggests that the catalytic oxidation of hydrocarbons is via a $\mathrm{Ru}=\mathrm{O}$ intermediate.

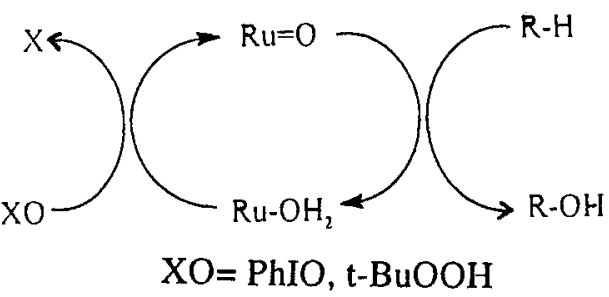

Scheme 3

Neutral ruthenium-oxo complexes have also been prepared. Oxidation of [RuIl(porp)CO] with $m$-chloroperoxybenzoic acid in a dichloromethanealcohol solution leads to the isolation of $\left[\mathrm{Ru}^{\mathrm{VI}}(\right.$ porp $\left.) \mathrm{O}_{2}\right]$ in high yields. This synthetic methdology is applicable to different trans-dioxoruthenium(VI) porphyrins including those with sterically bulky $(19,20)$ and non-sterically bulky porphyrins (21). Although the 1e-reduction $\mathrm{E}^{\circ}$ of $\left[\mathrm{Ru}^{\mathrm{VI}}\right.$ (porp) $\left.\mathrm{O}_{2}\right]$ are low, these complexes can oxidize the $3^{\circ}(\mathrm{C}-\mathrm{H})$ bonds of methylcyclohexane and adamantane to give 1-methylcyclohexanol 1-adamantanol respectively in reasonable yields (22). Although the kinetic isotope effect for the oxidation of saturated $\mathrm{C}-\mathrm{H}$ bonds had not been determined due to the slowness of the reaction, oxidation of cyclohexene by $\left[\mathrm{Ru}^{\mathrm{VI}}(\mathrm{TPP}) \mathrm{O}_{2}\right]\left(\mathrm{H}_{2} \mathrm{TPP}=\right.$ tetraphenylporphyrin) proceeds with a kinetic isotope effect of 11.7 (22). This would suggest a $[\mathrm{Ru}=\mathrm{O}--\mathrm{-H}-\mathrm{C}-\mathrm{]}$ transition state for the oxidation as that described above. With $\left[\mathrm{RuVI}^{\mathrm{V}}(\mathrm{TCDP}) \mathrm{O}_{2}\right]\left[\mathrm{H}_{2} \mathrm{TCDP}=\right.$ meso-(tetrakis $(2,6-$ dichlorophenyl)porphyrin] as catalyst (19), oxidation of cyclohexane to cyclohexanol and cyclohexanone by $\mathrm{t}-\mathrm{BuOOH}$ has been observed but the yield of organic products with respect to the consumption of $\mathrm{BuOOH}$ are disappointingly low ( less than 10\%).

Alkene oxidation by $\mathrm{Ru}=\mathrm{O}$ complexes have been demonstrated in many instances. The reactions for most of the cationic macrocyclic $\mathrm{Ru}=\mathrm{O}$ complexes are not selective, charge-transfer in nature, and usually lead to cleavage of $\mathrm{C}=\mathrm{C}$ bond (2). Two classes of sterically bulky $\mathrm{Ru}=\mathrm{O}$ complexes were found to undergo concerted oxygen atom transfer reactions with alkenes. The first is

TABLE 4. Second order rate constants for the epoxidation of alkenes by $\mathrm{Ru} \mathrm{VI}_{(\mathrm{TCDP}) \mathrm{O}_{2}}$ and $\mathrm{Ru}^{\mathrm{VI}}\left[2,4,6-(\mathrm{MeO})_{3} \mathrm{TPP} \mathrm{O}_{2}\right.$ at $35^{\circ} \mathrm{C}$ (solvent: dichloromethane)

\begin{tabular}{|c|c|c|c|c|c|}
\hline & \multicolumn{2}{|c|}{ Rate CoefTicient, $10^{3} \mathrm{k}_{2}$} & & \multicolumn{2}{|c|}{ Ratc Coc/Ticien!, $10^{3} \mathrm{k}_{2}$} \\
\hline Subsirales & $\mathrm{Ru}^{\mathrm{VI}}(\mathrm{TCDP}) \mathrm{O}_{2}$ & $\begin{array}{l}\mathrm{Ru}_{[2,4,6-} \\
(\mathrm{MeO})_{3} \mathrm{TPP}_{2} \mathrm{O}_{2}\end{array}$ & Substrales & $\mathrm{Ru}_{\mathrm{u}} \mathrm{VI}_{(\mathrm{TCDP}) \mathrm{O}_{2}}$ & $\begin{array}{l}\mathrm{RuVI}_{[2,4,6-} \\
(\mathrm{MeO})_{3} \mathrm{TPP}_{3} \mathrm{O}_{2}\end{array}$ \\
\hline Slyrene & $7.2 \pm 0.2$ & $1.09 \pm 0.03$ & 2,3-dimetliylbut-2-ene & $\approx 2^{*}$ & \\
\hline Norbornylenc & $27.9 \pm 0.5$ & $1.56 \pm 0.05$ & cis-stilbene & $2.9 \pm 0.1$ & $0.24 \pm 0.01$ \\
\hline cis-Cyclooclene & $2.0 \pm 0.2$ & $0.420 \pm 0.005$ & Irans-stilbente & $<0.1^{*}$ & $\approx 0.1^{*}$ \\
\hline I-hexene & $0.36 \pm 0.01$ & & cis- $\beta$-melhylstyrene & $6.8 \pm 0.2$ & \\
\hline trans- $\{-$-melhylslyrenc & $3.1 \pm 0.3$ & $2.0 \pm 0.1$ & & & \\
\hline
\end{tabular}

* The mensured rale cocfficicints flictuated form run to run by about $100 \%$, so the valucs are approximaled. 
trans-dioxoruthenium(VI) of sterically bulky porphyrins (19). Epoxidation of cis- and trans-stilbene by $\left[\mathrm{RuVI}^{\mathrm{VI}}(\mathrm{TPP}) \mathrm{O}_{2}\right]$ and $\left[\mathrm{Ru}^{\mathrm{VI}}(\mathrm{TCDP}) \mathrm{O}_{2}\right]$ are stereoretentive giving cis- and trans-stilbene oxide respectively (22). Table 4 lists the second-order rate constants for the epoxidation of alkenes by $\left[\mathrm{Ru}^{\mathrm{VI}}(\mathrm{TCDP}) \mathrm{O}_{2}\right]$ and $\left[\mathrm{Ru}^{\mathrm{VI}}\left(2,4,6-(\mathrm{MeO})_{3} \mathrm{TPP}\right) \mathrm{O}_{2}\right]\left[\mathrm{H}_{2}\left(2,4,6-(\mathrm{MeO})_{3} \mathrm{TPP}=\mathrm{meso}-\right.\right.$ tetrakis(2,4,6-trimethoxyphenyl)porphyrin]. The large dependence of rate constants on alkene structure argues for a concerted oxygen atom transfer mechanism. Detailed kinetic studies also revealed that the $\Delta S \#$ values are sensitive to both the structure of alkene and peripheral substituents of porphyrin. Another class of complexes is $\left[\mathrm{Ru}^{\mathrm{IV}}\left(\mathrm{Me}_{3} \operatorname{tacn}\right)(\mathrm{L}-\mathrm{L}) \mathrm{O}\right]^{2+}(\mathrm{L}-\mathrm{L}=$ substituted 2,2'-bipyridines) which are cationic and sterically bulky (23). Steroretentive epoxidation of cis-and trans-stilbene by these complexes have also been observed. Our kinetic studies also showed that $\Delta S \#$ of the reaction are sensitive to the alkene structure.

\section{PHOTOCHEMICAL GENERATION OF HIGHLY OXIDIZING OSMIUM(VI)-OXO COMPLEXES.}

A convenient mean to generate highly oxidizing metal-oxo complexes is the irradation of uv-visible light. While trans-dioxoosmium(VI) is usually unreactive and has low $E^{0}$ value, uv-visible excitation of these complexes lead to a long-lived excited state in fluid solution at room temperature. trans-[OsVI(TMC) $\left.\mathrm{O}_{2}\right]^{2+}$ is an important photooxidant since its ${ }^{3}\left[\left(d_{x y}\right)^{1}\left(d_{x z}, d_{y z}\right)^{1}\right]$ excited state has a lifetime of about $1.0 \mu \mathrm{s}$ and a Eo [ $\mathrm{Os}(\mathrm{VI}) * / \mathrm{Os}(\mathrm{V})]=2.2-2.3 \mathrm{~V}$ vs. $n$.h.e. in solution at room temperature $(6,7)$. A modified Latimer diagram of this Os(VI) complex is shown in Fig.3. Our studies showed that it can oxidize both aromatic hydrocarbons and alkenes upon uv-visible irradation in acetonitrile solution. Studies by Creutz and coworkers (24) established that the rate constant for oxidation of $\mathrm{Cl}^{-}$and $\mathrm{OH}^{-}$ by the ${ }^{3}\left[\left(d_{x y}\right)^{1}\left(d_{x z}, d_{y z}\right)^{1}\right]$ is $4 \times 10^{5}$ and $1 \times 10^{7} \mathrm{M}^{-1} s^{-1}$ respectively. Neutral trans-dioxoosmium(VI) complexes that bear $\mathrm{CN}^{-}$and polypyridine ligands have also been found to have emissive ${ }^{3}\left[\left(d_{x y}\right)^{1}\left(d_{x z}, d_{y z}\right)^{1}\right]$ excited state in solution at room temperature (25). Table 5 lists the photophysical properties of these complexes. Their excited state lifetimes are considerably shorter than that of trans-[Os $\left.\mathrm{VI}(\mathrm{TMC}) \mathrm{O}_{2}\right]^{2+}$ presumably this is due to the non-rigidity of the complexes.

\section{ELECTROPHILIC RUTHENIUM AND OSMIUM-NITRIDO COMPLEXES}

$\mathrm{Ru} \equiv \mathrm{N}$ and $\mathrm{Os} \equiv \mathrm{N}$ complexes are not uncommon in literature. However, no

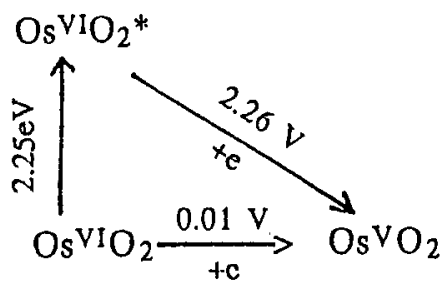

Fig.3 A modified Latimer diagram of trans-[Os $\mathrm{VI}_{\left.(\mathrm{TMC}) \mathrm{O}_{2}\right]^{2+}}$

TABLE 5. Emission data of some neutral Os(VI)-oxo complexes $\left[4,4^{\prime}-\mathrm{Me} 2 \mathrm{bpy}=4,4^{\prime}\right.$-dimethyl-2,2'bipyridine, TMEA $=\mathrm{N}, \mathrm{N}, \mathrm{N}^{\prime}, \mathrm{N}^{\prime},-$ tetramethyl-1,2diaminoethane, $\mathrm{t}$-Bu2 $\mathrm{bpy}=4,4^{\prime}$-ditert-2,2'-bipyridine].

\begin{tabular}{|c|c|c|}
\hline Complex & Emission $_{\max } / 1 \mathrm{~mm}$ & lifetime/ $\mu \mathrm{s}$ \\
\hline $\mathrm{Os}^{\mathrm{v} /} \mathrm{O}_{2}(\mathrm{CN})_{2}\left(4,4^{\prime}-\mathrm{Me}_{2} \mathrm{bipy}\right)$ & $658^{\pi}$ & .48 \\
\hline $\mathrm{Os}^{\mathrm{V} /} \mathrm{O}_{2}(\mathrm{CN})_{2}$ (TMEA) & $651^{n}$ & 41 \\
\hline 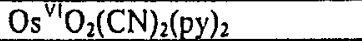 & $691^{6}$ & $<0.04$ \\
\hline$\left[\mathrm{Os}^{\mathrm{V}} \mathrm{O}_{2}(\mathrm{CN})_{4}\right]\left[\mathrm{nBu} \mathrm{nu}_{4} \mathrm{~N}\right]$ & $710^{\prime \prime}$ & .40 \\
\hline $\mathrm{Os}^{\mathrm{VI}} \mathrm{O}_{2}\left(\mathrm{t}-\mathrm{Bu}_{2} \mathrm{bipy}\right) \mathrm{Cl}_{2}$ & $742^{\circ}$ & \\
\hline
\end{tabular}


cationic $\mathrm{Ru} \equiv \mathrm{N}$ complex (2) is known. It is well established that oxidation of $\mathrm{Ru}-\mathrm{NH}_{3}$ would lead to the formation of $\mathrm{Ru}(\mathrm{II})-\mathrm{NO}$ (4). The reactive intermediate was proposed to be a high-valent $\mathrm{Ru} \equiv \mathrm{N}$ species ( Scheme 1). We suggest that the highly oxidizing ruthenium ion would cause intramolecular oxidation of the bound nitride to nitrosyl. If this is the case, the use of $\mathrm{NH}_{3}$ and/or primary amine as auxiliary ligand would give rise to high-valent but less oxidizing cationic $R u(V I) \equiv N$ and $R u(V) \equiv N$ complexes. We found that oxidation of $\left[\mathrm{Ru}\left(\mathrm{NH}_{3}\right)_{5} \mathrm{Cl}\right] \mathrm{Cl}_{2}$ by $\mathrm{Ce}(\mathrm{IV})$ in aqueous solution gives $\left.\left[\mathrm{Ru} \mathrm{VI}_{(\mathrm{NH}}\right)_{4} \mathrm{~N}\right] \mathrm{Cl}_{3}$, which is isolated as a diamagnetic yellow solid (26). Upon reaction with water, this complex was slowly converted to $\left[\mathrm{Ru}\left(\mathrm{NH}_{3}\right)_{4} \mathrm{NO}(\mathrm{OH})\right]^{2+}$. A binuclear cationic $\mathrm{Ru}(\mathrm{VI})$-nitrido complex has also been isolated. Treatment of $\left[\mathrm{Ru}^{\mathrm{VINCl}} \mathrm{N}^{-}\right.$with 2,5-diamino-2,3dimethylhexane (L) gives the $\left\{\left[\mathrm{Ru}_{\mathrm{VI}} \mathrm{N}(\mathrm{L})\right]_{2}(\mu-\mathrm{O})\right\}^{4+}$, the structure of which has been determined by $\mathrm{x}$-ray crystal analysis to contain a $\mathrm{N} \equiv \mathrm{Ru}-\mathrm{O}-\mathrm{Ru} \equiv \mathrm{N}$ unit (27). Oxidation of $\left[\mathrm{Os}\left(\mathrm{NH}_{3}\right)_{5} \mathrm{Cl}\right]^{2+}$ by $\mathrm{Ce}(\mathrm{IV})$ also gives the cationic $\left[\mathrm{Os}^{\mathrm{VI}}\left(\mathrm{NH}_{3}\right)_{4} \mathrm{~N}\right]^{3+}$, isolated as a chloride salt (8). The reaction of $\left[\mathrm{OsNCl}_{4}\right]^{-}, 2,3-$ diamino-2,3-dimethylbutane (tmen) and terpyridine gives the cationic $\left[\mathrm{OsVI}^{\mathrm{V}}(\text { tmen })_{2} \mathrm{Cl}\right]^{2+}(9)$ and $\left[\mathrm{OsVI}^{2} \text { (terpyridine) } \mathrm{NCl}_{2}\right]^{2+}(28)$ respectively. Electrochemically, these complexes undergo proton-coupled electron transfer reaction to give $\mathrm{Os}(\mathrm{III})-\mathrm{NH}_{3}$. However, the $3 \mathrm{H}^{+}-3 \mathrm{e} \quad\left[(\mathrm{Os}(\mathrm{VI}) \equiv \mathrm{N}) / \mathrm{Os}(\mathrm{III})-\mathrm{NH}_{3}\right]$ couple is not reversible in the cyclic voltammetric time scale. An intriguing property of $\mathrm{Os}(\mathrm{VI}) \equiv \mathrm{N}$ is that these complexes also possess the long-lived and emissive ${ }^{3}\left[\left(d_{x y}\right)^{1}\left(d_{x z}, d_{y z}\right)^{1}\right]$ excited state. As with trans-[OsVI $\left.(T M C) O_{2}\right]^{2+}$, $\left[\mathrm{Os}^{\mathrm{VI}}\left(\mathrm{NH}_{4}\right)_{4} \mathrm{~N}\right]^{3+}$ is a powerful photo-oxidant with a EO[Os(VI)*-Os(V)] of $2.3 \mathrm{~V}$ vs n.h.e. (8). Photoexcitation of $\left[\mathrm{Os}^{\mathrm{VI}}\left(\mathrm{NH}_{3}\right)_{4} \mathrm{~N}\right]^{3+}$ in the presence of 1,4dimethoxybenzene resulted in a nitrido coupling reaction which leads to the formation of the mixed valence $\left.\left[\mathrm{Os}_{2}\left(\mathrm{NH}_{3}\right)_{8}\left(\mathrm{CH}_{3} \mathrm{CN}\right)_{2}\right]\left(\mu-\mathrm{N}_{2}\right)\right\}^{5+}$. Detailed kinetic studies revealed the following reaction scheme.

$$
[\mathrm{Os} v \mathrm{vl} \equiv \mathrm{N}]^{3+}+\mathrm{D} \longrightarrow \mathrm{hv} \longrightarrow\left[\mathrm{Os}^{\mathrm{v} \equiv \mathrm{N}}\right]^{2+}+\mathrm{D}^{+}
$$

Scheme 4

$$
\left[\mathrm{Os}^{\mathrm{Vl}}=\mathrm{N}\right]^{3+}+\left[\mathrm{Os}^{\mathrm{Vl}}=\mathrm{N}\right]^{2+} \longrightarrow\left[\mathrm{Os}{ }^{\mathrm{II}-\mathrm{N}}=\mathrm{N}-\mathrm{Os}^{\mathrm{III}}\right]^{5+}
$$

$\mathrm{D}=$ aromatic donor

The coupling between $\left[\mathrm{Os}^{\mathrm{V}}\left(\mathrm{NH}_{3}\right)_{4} \mathrm{~N}\right]^{2+}$ and $\left[\mathrm{Os} \mathrm{VI}\left(\mathrm{NH}_{3}\right)_{4} \mathrm{~N}\right]^{3+}$ appears to be a one-step reaction with a second order rate constant of $3.75 \times 10^{5} \mathrm{M}^{-1} \mathrm{~s}^{-1}$. This is indeed a very fast reaction despite it involves the synchronized transformation of two Os $\equiv \mathrm{N}$ units to a bound dinitrogen molecule. Thus the electrophilic $O s \equiv N$ and $R u \equiv N$ complexes serve as good model for study of biological nitrite reductase and dinitrogen activation reaction.

\section{IMIDO AND AMIDO COMPLEXES OF RUTHENIUM AND OSMIUM}

Osmium-imido complexes are not uncommon in literature but there are only a few examples of ruthenium-imido complexes. We found that similar to the preparation of $\mathrm{Ru}=\mathrm{O}$ complexes, oxidative deprotonation of $\mathrm{Ru}-\mathrm{NH}_{2} \mathrm{R}$ provides a simple entry to high-valent $\mathrm{Ru}=\mathrm{NR}$ complexes (29). Thus bromine oxidation of $\left[\mathrm{Ru}(\right.$ porp $\left.)\left(\mathrm{NH}_{2} \mathrm{Bu}^{\mathrm{t}}\right)_{2}\right]$ gives $\left[\mathrm{Ru}^{\mathrm{VI}}\right.$ (porp)O $\left.\left(\mathrm{NBu}^{\mathrm{t}}\right)\right]$ in reasonable yields. These $\mathrm{Ru}=\mathrm{NBut}$ complexes are air stable solid but rapidly react with triphenylphosphine within a few minutes. The isoelectronic $\left[\mathrm{Os}^{\mathrm{VI}}(\right.$ porp $\left.) \mathrm{O}\left(\mathrm{NBu}^{t}\right)\right]$ and $\left[\mathrm{Os}^{\mathrm{VI}}(\right.$ porp $\left.)\left(\mathrm{NBu}^{\mathrm{l}}\right)_{2}\right]$ are prepared by similar method 
Oxidative deprotonation

$\mathrm{n}, \mathrm{m}=1$ or 2

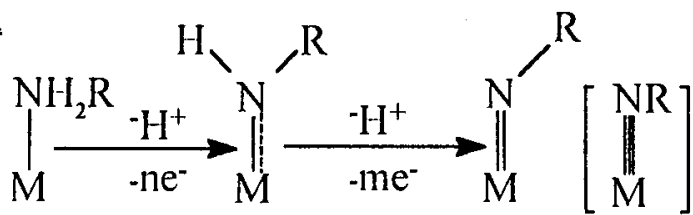

and their structure determined by $x$-ray crystal analysis. $\left[\mathrm{Ru}^{\mathrm{VI}}(\mathrm{TPP})\left(\mathrm{NBu} \mathrm{t}_{2}\right]\right.$ has also been prepared but this easily react with water to give $\left[\mathrm{RuVI}(\mathrm{TPP}) \mathrm{O}\left(\mathrm{NBu} \mathrm{u}^{\mathrm{t}}\right)\right]$. Another method to generate imido and amido complexes of ruthenium and osmium is electrochemical oxidation of the metal-amine precursor. This is quite similar to the proton coupled electron transfer reactions, which have been commonly encountered for both $\mathrm{Ru}=\mathrm{O}$ and $\mathrm{Os}=\mathrm{O}$. In this context, the ligand 2,3-diamino-2,3-dimethylbutane is chosen for the study because its deprotonated forms are good chelating donor.

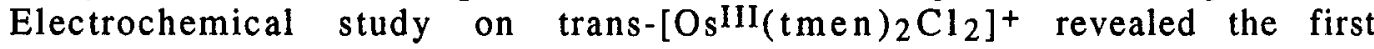
observation of reversible Os(IV)-amido/Os(III)-amine couple (30).

$$
\mathrm{Os}^{\mathrm{IV}}-\mathrm{NHR}+\mathrm{H}^{+}+\mathrm{e} \longrightarrow \mathrm{Os}^{\mathrm{III}}-\mathrm{NH}_{2} \mathrm{R}
$$

Similar electrochemical reactions have also been encountered with $\mathrm{Ru}$-tmen complexes. For $\left[\mathrm{Ru}\left(2,2^{\prime} \text {-bipyridine }\right)_{2}(\mathrm{tmen})\right]^{2+}(31)$, a reversible $3 \mathrm{e}-3 \mathrm{H}^{+}$ $\mathrm{Ru}(\mathrm{V})$-imido/Ru(II)-amine couple is observed in aqueous solution, the $\mathrm{E}^{\mathrm{O}}$ of which shifts by about $-60 \mathrm{mV}$ per $\mathrm{pH}$ unit.

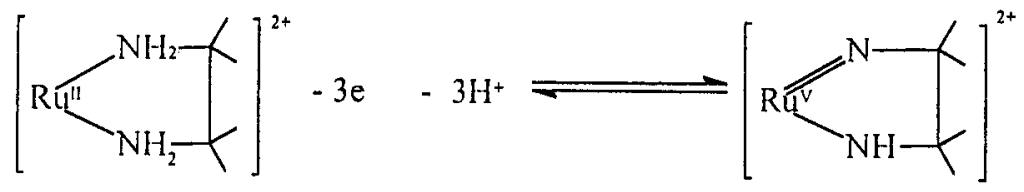

By reacting $\left[\mathrm{Ru}^{\mathrm{VINCl}}\right]^{-}$with tmen, a novel cis-bis(amido)ruthenium(IV) complex, $\left[\mathrm{Ru}^{\mathrm{IV}}(\text { tmen })(\text { tmen }-\mathrm{H})_{2}\right]^{2+}$, has been isolated and characterised by $\mathrm{x}$ ray crystal analysis $(26,27)$. The $\mathrm{Ru}-\mathrm{N}$ (amido) distances in this complex are $1.835(7)$ and $1.850(8) \mathrm{A}$, indicative of very strong $\mathrm{d} \pi-\mathrm{p} \pi$ interaction.

Acknowledgement. Financial supports from The University of Hong Kong and Hong Kong Research Grants Council are gratefully acknowledged.

\section{REFERENCES}

1. W.A. Nugent and J.M. Mayer. Metal Ligand Multiple Bonds ,Wiley, New York, (1988).

2. C.M. Che and V.W.W. Yam. Adv. Inorg.Chem., 39, 233 (1992).

3. D.T. Sawyer. Comm.Inorg.Chem., 6, 103 (1987).

4. W.R. Murphy, Jr., K. Takeuchi, M.H. Barley, and T.J. Meyer.Inorg.Chem., 25, 1041 (1986).

5. J.D. Buhr and H. Taube. Inorg. Chem., 18, 2208 (1979).

6. V.W.W. Yam and C.M. Che. J.Chem.Soc.Dalton Trans., 3741 (1990).

7. V.W.W. Yam and C.M. Che. Coord.Chem.Rev., 97, 93 (1990)

8. H.W. Lam, C.M. Che and K.Y. Wong. J.Chem.Soc.Dalton Trans., 1411 (1992) 
9. C.M. Che, K.Y. Wong, H.W. Lam, K.F. Chin, Z.Y. Zhou, and T.C.W. Mak. J.Chem.Soc.Dalton Trans., 857 (1993).

10. C.M. Che and W.O. Lee. J.Chem.Soc.Chem.Commun., 881 (1988).

11. C.M. Che, W.H. Leung, C.K. Li, and C.K. Poon. J.Chem.Soc.Dalton Trans., 379 (1991).

12. C.M. Che, V.W.W. Yam, and T.C.W. Mak.J.Am.Chem.Soc., 112, 2284 (1990).

13. W.C. Cheng, W.Y. Yu, K.K. Cheung, and C.M. Che, J.Chem.Soc.Chem.Commun., 1063 (1994).

14. a) C.M. Che, C. Ho, and T.C. Lau, J.Chem.Soc.Dalton Trans. 1901 (1991). b)

C. Ho, T.C. Lau, and C.M. Che, J.Chem.Soc.Dalton Trans., 1259 (1991).

15. C.M. Che, C. Ho, W.O. Lee, and T.C. Lau, Preprints, Symposium on Oxygen Activation in Catalysis, Division of Petroleum Chemistry, Inc., American Chemical Society, No.2.35, 179 (1990).

16. C.M. Che, W.T. Tang, W.O. Lee, K.Y. Wong, and T.C. Lau. J.Chem.Soc.Dalton Trans., 1551 (1992).

17. C.M. Che, W.T. Tang, and C.K. Li. J.Chem.Soc.Dalton Trans., 3277 (1991).

18. T.C. Lau, C.M. Che, W.O. Lee, and C.K. Poon. J.Chem.Soc.Chem.Commun., 1406 (1988).

19. C.H. Yeung. PhD Thesis, The University of Hong Kong (1994).

20. J.T. Groves and R. Quinn.Inorg.Chem., 23, 3844 (1984).

21. W.H. Leung and C.M. Che, J.Am.Chem.Soc., 111, 8812 (1989).

22. C. Ho, W.H. Leung and C.M. Che. J.Chem.Soc.Dalton Trans., 2933 (1991).

23. W.C. Cheng, W.Y. Yu, K.K. Cheung, and C.M. Che, J.Chem.Soc.Dalton Trans., 57 (1994).

24. S. Schindler, E.W. Castner, Jr., C. Creutz, and N. Sutin. Inorg.Chem., 32, 4200 (1993).

25. K.F. Chin and C.M. Che, unpublished results.

26. W.H. Chiu and C.M. Che, unpublished results.

27. K.K. Cheung and C.M. Che, unpublished results.

28. D.W. Pipes, M. Bakir, S.E. Vitols, D.J. Hodgson, and T.J. Meyer, J.Am. Chem. Soc. 112, 5507 (1990).

29. J.S. Huang, C.M. Che, and C.K. Poon. J.Chem.Soc.Chem.Commun., 161 (1992).

30. K.F. Chin, K.Y. Wong, and C.M. Che, J.Chem.Soc.Dalton Trans., 197 (1993).

31. K.Y. Wong, C.M. Che, C.K. Li, W.H. Chiu, and T.C.W. Mak, J.Chem. Soc.Chem. Commun., 754 (1992). 